\title{
"Diskret" Papüler Müsinoz: Liken Miksödematozun Nadir Bir Subtipi
}

\section{Discrete Papular Mucinosis-A Rare Subtype of Lichen Myxoedematosus}

\author{
Havva Kaya Akış, Fatma Eskioğlu, Evrim Öztürk* \\ Dışkapı Yıldırım Beyazıt Eğitim ve Araşıırma Hastanesi, Deri ve Zührevi Hastalıklar Kliniği, Ankara, Türkiye \\ *Dışkapı Yıldırım Beyazıt Eğitim ve Araştırma Hastanesi, Patoloji Kliniği, Ankara, Türkiye
}

\section{Özet}

Liken miksödematoz (papüler müsinoz) tiroid hastalığı olmaksızın dermal müsin birikimi ve fibrozise bağlı olarak gelişen likenoid papül, nodül ve/veya plaklar ile karakterize sık görülmeyen, kronik, idiyopatik bir hastalıktır.Liken miksödematoz klinikopatolojik olarak iki subgrup içerir: monoklonal gammopati ile beraber sistemik, hatta letal bulguları olan generalize papüler ve sklerodermoid form (skleromiksödem de denir) ve daha selim prognozlu lokalize papüler form. "Discrete" papüler müsinoz, Hepatit C virüs (HCV) ve insan immünyetmezlik virüs (HIV) infeksiyonu ile ilişkili olabilen lokalize formun nadir bir subtipidir.Bugüne kadar literatürde HCV veya HIV infeksiyonu ile ilişkisi olmayan sadece 12 olgu bildirimi vardır. Burada vücudunda çok sayıda, asemptomatik, deri renginde papülleri olan, histopatolojik incelemede dermal müsin birikimi tespit edilen, tiroid hastalığı ve monoklonal gammopati saptanmayan, viral belirleyicileri negatif olan 64 yaşında kadın hastayı sunuyoruz. (Türkderm 2011; 45: 104-6)

Anahtar Kelimeler: Papüler müsinoz, skleromiksödem

\section{Summary}

Lichen myxoedematosus (synonym, papular mucinosis) is an uncommon, chronic, idiopathic disorder characterized by lichenoid papules, nodules and/or plaques due to dermal mucin deposition and a variable degree of fibrosis in the absence of thyroid dysfunction. Actually, lichen myxoedematosus includes two clinicopathologic subsets: a generalized papular and sclerodermoid form (also called scleromyxedema) with a monoclonal gammopathy and systemic, even lethal, manifestations and a localized papular form with non-disabling course. Discrete papular mucinosis is a rare subtype of the localized form and can be associated with hepatitis C virus and human immunodeficiency virus (HIV) infection. Only 12 cases unrelated to HCV or HIV infection have been described in the literature to date. Herein, we report a 64-year-old woman who presented with asymptomatic, flat, flesh-coloured papules on her neck, upper trunk and proximal extremities. A skin biopsy from a papule on her neck demonstrated dermal mucin deposition after alcian blue staining. The number of fibroblasts was increased. Laboratory studies revealed normal thyroid function tests. Serum protein electrophoresis did not show any evidence of a monoclonal gammopathy. Serology tests for HCV and HIV were negative. (Turkderm 2011; 45: 104-6)

Key Words: Papular mucinosis, scleromyxedema

\section{Giriş}

Liken miksödematoz (papüler müsinoz) tiroid hastaığı olmaksızın, dermal müsin birikimi ve değişik derecelerde fibroblast proliferasyonun neden olduğu likenoid papül, nodül ve/veya plaklarla karakterize kronik idiyopatik bir hastalıktır ${ }^{1,2}$. Liken miksödema- toz ilk kez 1906 'da Dubrevilh ve 1908 'de Reitman tarafından tanımlanmıştır, 1953 yılında Montgomery ve Underwood tarafından skleroderma ve generalize miksödemden farklı bir hastalık olduğu ortaya konulmuş ve ilk sınıflandırması yapılmıştır ${ }^{3} .2001$ yılında ise Rongioletti liken miksödematoz sınıflamasını yenilemiştir. Buna göre liken miksödematoz , 2 kliniko-

Yazışma Adresi/Address for Correspondence: Dr. Havva Kaya Akıss, Dışkapı Yıldııım Beyazıt Eğitim ve Araştırma Hastanesi, Dermatoloji Kliniği, Ankara, Türkiye Tel: +90 3125962083 E-posta: hawwakaya@yahoo.com Geliş Tarihi/Received: 12.02.2010 Kabul Tarihi/Accepted: 07.09.2010 
patolojik subtip içerir: generalize papüler ve sklerodermoid form (skleromiksödem) ve lokalize papüler form. "Discrete" papüler müsinoz (DPM), lokalize papüler formun nadir bir subtipidir', hepatit $C$ virus (HCV) ve insan immünyetmezlik virüs (HIV) infeksiyonları ile ilişkili olabileceğinden erken tanınması önemlidir ${ }^{4}$.

\section{Olgu Sunumu}

Altmış dört yaşında kadın hasta boyun, gövdenin üst kısmı, sırt ve üst ekstremitelerinde çok sayıda asemptomatik, deri renginde papüller ile polikliniğimize başvurdu. Papüller ilk defa 2 yıl önce boyun bölgesinde ortaya çıkmış, zaman içinde diğer bölgelere de yayılarak sayısı artmıştı. Hastanın öz ve soygeçmişinde belirgin özellik yoktu. Sistemik semptom sorgulamasında yutma güçlüğü, kas güçsüzlüğü, ses kısıklığı, eklem şişliği, kardiyovasküler ve nörolojik sisteme ait semptom olmadığı öğrenildi. Sistemik fizik muayenesi normaldi. Dermatolojik muayenede boyun ve ensede, gövde ön yüzü, sırt ve her iki üst ekstremite proksimalinde çok sayıda, düzgün yüzeyli, deri renginde , 3-5 mm çapında papüller tespit edildi (Resim 1). Boyun bölgesindeki bir papülden alınan deri biyopsi örneğinin histopatolojik incelemesinde hematoksilen-eozin boyama ile yüzeyde ortokeratoz gösteren epidermis ile örtülü dokuda epidermisde hafif akantoz izlendi. Epidermisin hemen altından başlayarak üst dermisin mikzoid bir karakterde olduğu izlendi ve bu görünümün üst dermis ile sınırlı olduğu dikkati çekti. Bu alanda fibroblastlarda irileşme ve sayıca hafif artış mevcuttu (Resim 2, H\&EX200), alcian blue boyası ile dermisteki miksoid görünümün müsin birikimi olduğu saptandı (Resim 3, ABX200). Laboratuvar incelemelerinde rutin kan sayımı, biyokimya profili ve tiroid fonksiyon testleri normaldi. Antinükleer antikor düzeyi normal sınırlardaydı. Serum protein elektroforezinde monoklonal gammopati lehine bulgu yoktu. IgA, IgM, IgG düzeyleri normaldi. Hepatit B ve $C$ virüsler ile HIV için serolojik testler negatif idi. Klinik, histopatolojik ve laboratuvar bulgular eşliğinde hastaya DPM tanısı konuldu. Liken miksödematozun lokalize formunun sıklıkla deride sınırlı olmasına ve prognozunun da dolayısıyla iyi olmasına rağmen lezyonların spontan düzelme ihtimalinin nadir ol-

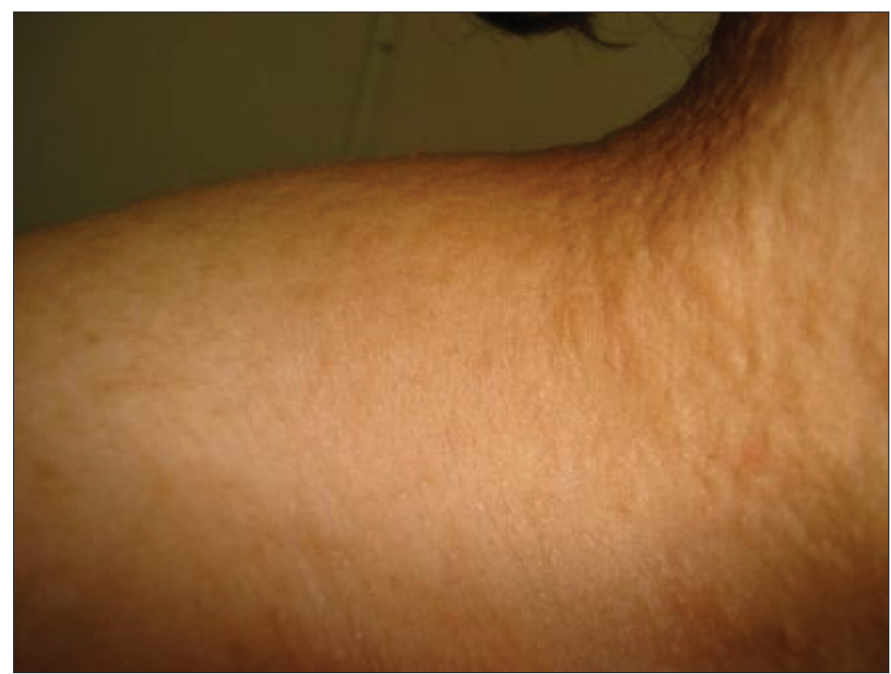

Resim 1. Hastamızın boyun ve sırtında çok sayıda, düzgün yüzeyli, deri renginde, 3-5 $\mathrm{mm}$ çapında papüller tespit edildi ması ve hastanın lezyonlarını kozmetik olarak rahatsız edici bulması nedeniyle $1 \mathrm{mgr} / \mathrm{kg} / \mathrm{gün}$ isotretinoin tedavisi başlandı. Üç aylık tedavi sonrası lezyonlarında hiç düzelme olmaması sonucu hastanın isteği ile tedavisi sonlandırıldı.

\section{Tartışma}

Liken miksödematoz, idiyopatik bir kutanöz müsinozdur. Müsin birikiminin patogenetik mekanizması tam olarak anlaşılamamış olmasından dolayı kutanöz müsinozların sınıflaması da karmaşıktır. Müsin birikiminin yerine göre dermal ve folliküler müsinozlar olarak; lupus eritematozus, lenfoma ve tiroid hastalığı gibi müsin birikimi ile ilişkili olan hastalıklarla birliktelik varlığı veya yokluğuna göre sekonder ve primer müsinozlar olarak ayrılırlar 5,6.

Liken miksödematoz, dermal müsin birikimine bağlı papül, nodül ve/veya plaklarla karakterize oldukça nadir, idiyopa-

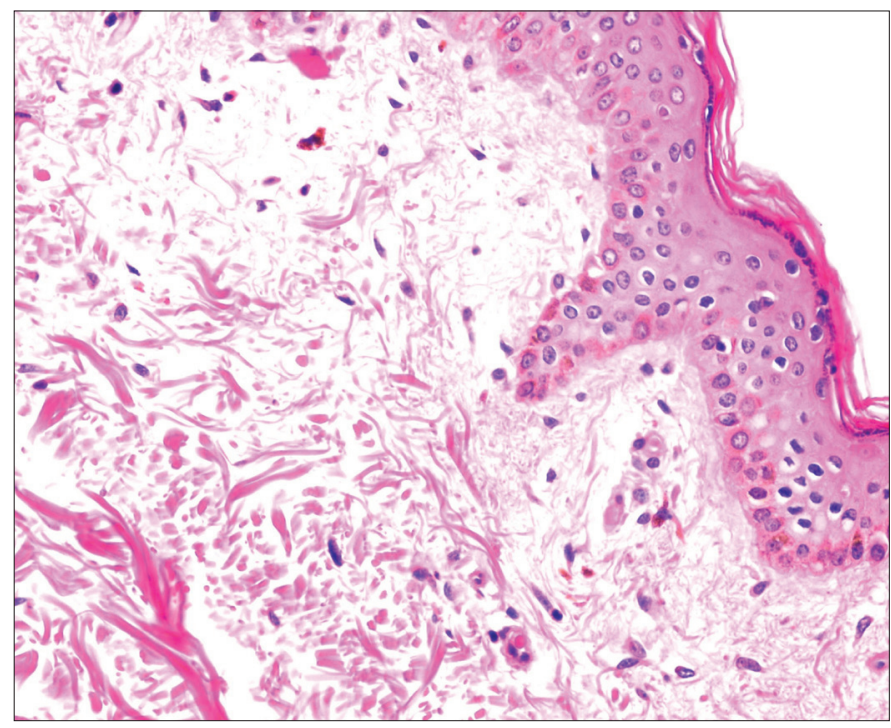

Resim 2. Epidermis altından başlayan ve üst dermise sınırlı olarak izlenen miksoid alan içerisinde fibroblastlarda belirginleşme görülmektedir ( Hematoksilen-EozinX200)

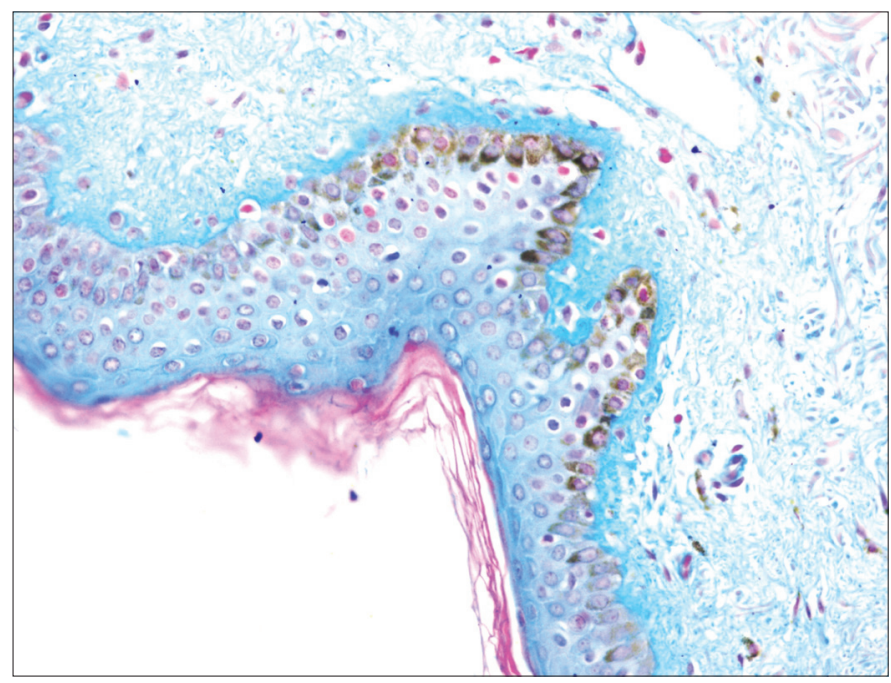

Resim 3. Üst dermisde alcian mavisi ile müsin birikimi izlenmektedir. (Alcian BlueX200) 
tik, kronik bir primer kutanöz müsinozdur ${ }^{1,2} .1953$ yılında Montgomery ve Underwood'un liken miksödematozu sınıflamasının ardından 2001 yılında Rongioletti yeni bir sınıflama ile liken miksödematoz ve subtipleri için tanı kriterlerini ortaya koymuştur. Bu sınıflamaya göre iki klinikopatolojik subtip vardır: (i) generalize papüler ve sklerodermoid form (skleromiksödem) ve (ii) lokalize papüler form ${ }^{1,3}$.

Skleromiksödem için tanı kriterleri: (1) generalize papüler ve sklerodermoid erüpsiyon: (2) müsin birikimi, fibroblast proliferasyonu ve fibrozis: (3) monoklonal gammopati varlığı ve (4) tiroid hastalığı olmamasıdır. Skleromiksödem sıklıkla 3080 yaş arası erişkinleri etkileyen nadir bir hastalıktır. Hastaların \%80'ninden fazlasında paraproteinemi, tipik olarak IgG kappa zinciri mevcuttur. Deri dışı bulgular kardiyovasküler, gastrointestinal, pulmoner,oküler, romatolojik ve santral sinir sistemini ilgilendirebilir, belirgin morbidite ve mortaliteye yol açabilir ${ }^{1,8-11}$. Kesin bir tedavisi olmamakla beraber tedavide birinci seçenek melfalan, sistemik kortikosteroid, plazmaferez, ikinci seçenek isotretnoin, etretinat, topikal ve intralezyonel kortikosteroidlerdir ${ }^{10,12}$

Lokalize papüler form için tanı kriterleri: (1) papüler veya nodüler/plak erüpsiyon: (2) müsin birikimi, değişik derecelerde fibroblast proliferasyonu ve (3) monoklonal gammopati ve tiroid hastalığı olmamasıdır. Bu iki form arasında ayırım yapılması önemlidir çünkü seyir, prognoz ve tedavi yaklaşımları farklıdır. Lokalize formun ayrıca herhangi bir vücut bölgesini tutan DPM; sadece el ve bileklerin ekstansör yüzeylerini tutan akral persistan papüler müsinoz; kendiliğinden iyileşen juvenil ve adult tipi olan papüler müsinoz; infantın papüler müsinozu ve nodüler formu içeren 5 subtipi vardır ${ }^{1}$. Bizim hastamız literatürde son derece nadir olarak bildirilmiş DPM tanı kriterlerini taşımaktadır. Bugüne kadar HCV veya HIV infeksiyonu ile ilişkisiz sadece 12 DPM olgusu tanımlanmıştır ${ }^{4}$. Klinik olarak ekstremitelerde ve gövdede simetrik olarak yerleşen 2-5 mm çapında, düzgün yüzeyli, deri renginde, sayısı birkaç adetten yüzlerce adete kadar değişebilen papüller görülür'1. Daha önceleri DPM için papül sayısının sıklıkla 50'den az olduğu kabul edilirken ${ }^{5,13}$ artık bu sayının yüzlerce olabileceği- bizim hastamızda olduğu gibi- bilinmektedir ${ }^{1}$. Tutulan deri bölgesinde indürasyon yoktur ve yüz sıklıkla korunmaktadır. Lezyonlar yavaş progresyon gösterir, sistemik tutulum olmaz. Ancak spontan düzelme son derece nadirdir. DPM'un klinik önemi hastalığın HCV veya HIV infeksiyonlarına eșlik edebilmesidir, tanısı bu nedenle önem kazanmaktadır ${ }^{4}$. Histopatolojik olarak üst ve orta dermiste diffüz veya lokal müsin birikimi, değişik derecelerde fibroblast proliferasyonu vardır, kollajen yapımı veya skleroz yoktur ${ }^{1,14-16}$. Ayırıcı tanısında yer alan liken planus, erüptif papüler ksantom, leiomyom ve likenoid ilaç erüpsiyonundan klinik ve histolojik olarak kolayca ayrılır ${ }^{5}$. Lokalize liken miksödematozun sıklıkla deride sınırlı olması ve dolayısıyla iyi prognozlu olması nedeniyle tedavi gerektirmemektedir. Ancak hastamız lezyonlarını kozmetik olarak rahatsız edici bulduğu için literatürde iyi sonuçlar alındığı bildirilen isotretionin tedavisini uygulamayı tercih ettik; $1 \mathrm{mgr} / \mathrm{kg} / \mathrm{gün}$ isotretinoin ile 3 aylık tedavi sonrası yanıt alınamaması üzerine hastanın isteği ile tedavi sonlandırıldı.

Klinik, histopatolojik ve laboratuvar bulguları ile tipik bir lokalize liken miksödematoz olgusu olan hastamızın bildirilmesiyle liken miksödematozun generalize skleodermoid ve lokalize papüler formlarının ayırımının yapılmasının bu iki subtipin seyir, prognoz ve tedavi yaklaşımları açısından tamamen farklı olmaları nedeniyle önem taşıdığını, ayrıca DPM subtipinin HCV ve HIV infeksiyonları ile ilişkili olabileceğinden erken tanınmasının önemini vurgulamak istedik.

\section{Kaynaklar}

1. Rongioletti F, Rebora A: Updated classification of papular mucinosis, lichen myxedematosus, and scleromyxedema. J Am Acad Dermatol 2001:44:273-81.

2. Rongioletti F: Lichen myxedematosus (papular mucinosis): new concepts and perspectives for an old disease. Semin Cutan Med Surg 2006;25:100-4.

3. Montgomery H, Underwood LJ: Lichen myxedematosus; differentiation from cutaneous myxedemas or mucoid states. J Invest Dermatol 1953;20:213-36.

4. Concheiro J, Perez-Perez L, Labandeira J, Toribio J: Discrete papular lichen myxoedematosus: a rare subtype of cutaneous mucinosis. Clin Exp Dermatol 2009;34:e608-e610.

5. Poswig A, Hinrichs R, Megahed M et al: Discrete papular mucinosis-a rare subtype of lichen myxoedematosus. Clin Exp Dermatol 2000;25:289-92.

6. Bachmeyer C, Chesneau AM, Loirat C, Asensi D, Babinet JM, Blum L: Papulonodular mucinosis in a child with systemic lupus erythematosus. Pediatr Dermatol 2007;24:585-6.

7. Harris JE, Purcell SM, Griffin TD: Acral persistent papular mucinosis. J Am Acad Dermatol 2004;51:982-8.

8. Heymann WR: Scleromyxedema. J Am Acad Dermatol 2007; $57: 890-1$.

9. Cokonis Georgakis CD, Falasca G, Georgakis A, Heymann WR: Scleromyxedema. Clin Dermatol 2006;24:493-7.

10. Lin YC, Wang HC, Shen JL: Scleromyxedema: An experience using treatment with systemic corticosteroid and review of the published work. J Dermatol 2006;33:207-10.

11. Gülcan $P$, Koç M, Baran F, Kocabaşoğlu C, Mudun AB: Göz bulguları ile birliktelik gösteren ve siklofosfamid tedavisine yanıt veren bir papüler musinoz olgusu. Türkderm 2006:40:88-92.

12. Desai $A$, James $W$ : Lichen myxedematosus. In: Lebwohl $M_{\text {, }}$ Heymann W, Berth-Jones J, Coulson I, editors. Treatments of skin disease: comprehensive therapeutic strategies. 2nd ed. Philadelphia(PA): Elsevier Science; 2006. p. 343-4.

13. Seike M, Ikeda M, Kodama H: Discrete papular mucinosis on the back. J Dermatol 2005;32:856-8.

14. Sáez-Rodríguez M, García-Bustínduy M, López-Alba A et al: Localized lichen myxoedematosus (papular mucinosis) associated with morbid obesity: report of two cases. $\mathrm{Br} J$ Dermatol 2003;148:165-8.

15. Yen A, Sanchez RL, Raimer SS: Papular mucinosis associated with AIDS: response to isotretinoin. J Am Acad Dermatol 1997;37:127-8.

16. Sperber BR, Allee J, James WD: Self-healing papular mucinosis in an adult. J Am Acad Dermatol 2004;50:121-3. 